\title{
THE LEVEL OF CRITICAL THINKING SKILL ON SOLVING TWO-DIMENSIONAL ARITHMETICS PROBLEMS THROUGH RESEARCH-BASED LEARNING
}

\author{
Suntusia Suntusia ${ }^{*}$ iD, Dafik Dafik ${ }^{2}$ iD Hobri Hobri $^{3}$ \\ 1 Universitas Bondowoso, Indonesia \\ 2,3Universitas Jember, Indonesia \\ ${ }^{1 *} \underline{\text { suntusiahafiza@gmail.com, }{ }^{2} \text { d.dafik@gmail.com, }{ }^{3} \text { hobri.fkip@unej.ac.id }}$
}

Received: January 4, $2021 \quad$ Revised: April 10, $2021 \quad$ Accepted: April 14, 2021

\begin{abstract}
:
Developing critical and collaborative thinking skills among learners was of significant importance in the 21st-century era. In this study, the researcher applied teaching and learning based on Research-Based Learning (RBL) to know the level of students critical thinking skill. The number of research samples was 30 students. This study used a triangulation research method, namely a combination of qualitative and quantitative methods. The quantitative method was obtained by using a learning outcome test and the qualitative method is obtained using a questionnaire and interview. Then the data that has been collected was analyzed using a t-test. Four students were chosen to represent critical thinking level 4, 13 students were chosen to represent Critical Thinking level 3, and 6 students were chosen to represent critical thinking level 2, 4 students were chosen to represent critical thinking level 1, and 3 students were chosen to represent critical thinking level 0. More subjects would be involved until the data was saturated. Students on low critical thinking were at Level 0 . Based on the interpretation result of the t-test value, there was a significant difference between the control class and the experimental class, proved by the 0.000 figure in the statistical analysis. Therefore, it proved a significant difference in learning outcomes. However, the data that we obtained present a significant difference between the control class and the experimental class below 0.05 . After we interpreted t-tabel $=2.04$ on degrees of freedom $0.025, t-$ count of 0.000 was evident. Thus, a hypothesis was accepted since it was below 0.025 . Qualitative methods show the results of interviews with 2 students.
\end{abstract}

Keywords: Critical Thinking Skill, Two-Dimensional Arithmetics, Research-Based Learning.

How to Cite: Suntusia, S., Dafik, D., Hobri, H. (2021). The Level of Critical Thinking Skill on Solving Two-Dimensional Arithmetics Problems Through Research-Based Learning. Alifmatika: Jurnal $\begin{array}{llll}\text { Pendidikan dan } \quad \text { Pembelajaran } & \text { 351), }\end{array}$ https://doi.org/10.35316/alifmatika.2021.v3i1.55-69

\section{Introduction}

The world continues to change as well as the world with education. Equally, the teaching and learning of Mathematics patterns must change with the aim of the education world to become relevant to the challenges and opportunities that occur in real life. In the current world of work, highly skilled college graduates are required to work in a team, solve problems, establish critical thinking skill, It master technology without on, and communicate effectively.

In Mathematics learning, especially on problems solving of two-dimension arithmetic, students are required to explore and demonstrate their critical thinking skills starting from finding the differences, filling the points and finding the 
differences, finding new patterns, and re-examining the problem solving that has been implemented. Critical thinking skills are classified as high order competencies and it can be viewed as a continuation of basic competencies, commonly referred in Mathematics learning. According to Tohir, Maswar, Atikurrahman, Saiful, \& Pradita (2020) said that effective mathematics learning is a step within creative thinking for each person which will have different abilities to solve a problem.

Critical thinking skill is the ability to analyse a situation or math problems through a rigorous examination. According to Sutawidjaja and Jarnawi (Faizah, Nusantara, Sudirman, \& Rahardi, 2020; Haryani, Hidayatullah, Yusuf, \& Asrowi, 2019; Mudayen \& Dalyono, 2018), Critical Thinking is a systematic process that allows students to formulate and evaluate their own beliefs and opinions. Mathematical critical thinking skills have indicators. Based on Ennis (Munawwarah, Laili, \& Tohir, 2020), critical thinking has six indicators including Focus, Reason, Inference, Situation, Clarity, and Overview. According to book P21 (Abidin \& Tohir, 2019), critical thinking consists of (1) reasoning effectively, (2) thinking systems, (3) making decisions, and (4) problem-solving skills.

This opinion is strengthened by Tohir, Abidin, Dafik, \& Hobri (2018) said that The guided research-based learning method, when integrated into Combinatorics, can successfully lead to the improved level of students critical thinking skills. These opinions are in accord with the research results obtained by Suntusia, Dafik, \& Hobri (2019) showed that the implementation of Research-Based Learning is proven effective in improving students learning achievement in solving twodimensional arithmetic problems according to research Suntusia, Dafik, \& Hobri (2019) showed that the implementation of Research-Based Learning is. This approach encourages students to understand and comprehend the relationship between learning science on campus and conducting scientific studies.

This study aims to compare the study between the experimental class and the control class. Comparing the level of critical thinking skills of students. 


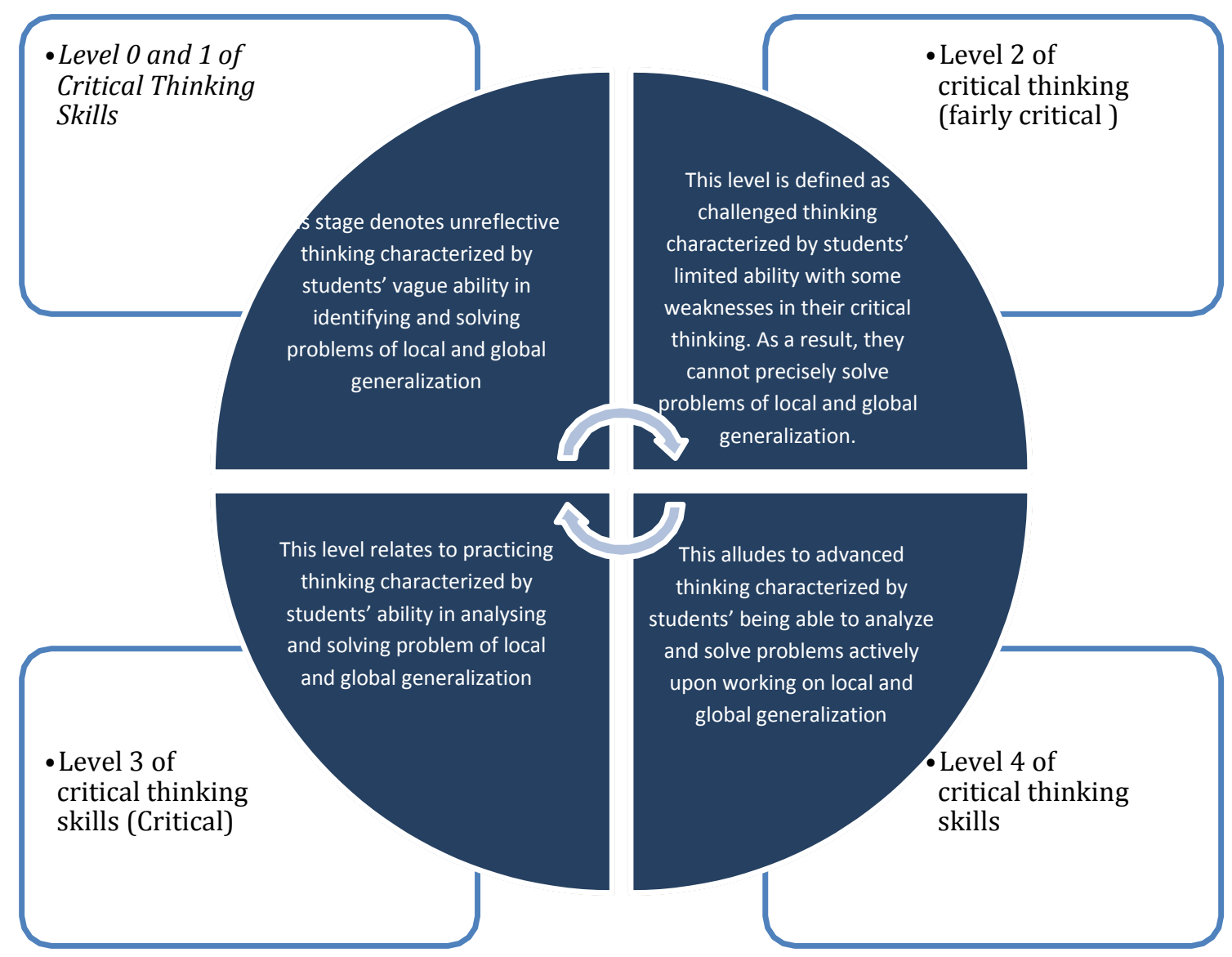

Figure 1. Revised Draft of the Critical Thinking Skills Level (CTSL) of Students

The adjustment indicators were used as the reference for the analysis. The indicators were adapted from Research-Based Learning (RBL) syntax and critical thinking rationale. The following is the formula operative in the study:

\section{Critical Thinking Skill Level}

The characteristics are adapted to learning under RBL

\begin{tabular}{l}
\hline Critical Thinking Skill Level 0-1 \\
Critical Thinking Skill Level 2 (fairly \\
critical)
\end{tabular}

able to identify and solve problems that are local generalization and global generalization that are not clear and limited. Students are difficult in carrying out most of the learning syntax.

able to identify and solve problems that are local generalization and global generalization that are clear and limited. The syntax of students is capable of design to the global generalization but there are difficulties in applying it. 


\begin{tabular}{ll}
$\begin{array}{l}\text { Critical Thinking Skill Level } 3 \\
\text { (Critical thinking ) }\end{array}$ & $\begin{array}{l}\text { able to analyse and actively solve } \\
\text { local problems of generalization and } \\
\text { global generalization. Students are } \\
\text { able to arrange the analysis results } \\
\text { without drawing the conclusions. }\end{array}$ \\
Critical Thinking Skill Level 4 & $\begin{array}{l}\text { Students are able to analyse and be } \\
\text { active in solving the problems of local } \\
\text { and global generalization. Students } \\
\text { are able to develop analysis results } \\
\text { and draw conclusions. }\end{array}$ \\
\hline
\end{tabular}

Iakovos (2011) explains that critical thinking has an important role in education and there are four important components of main objectives in learning to develop the students' ability: (a) explaining and clarifying; (b) asking and using the right questions to clarify or challenge; (c) considering the source of credibility; (d) problem solving and drawing conclusions. Forawi's study (2016) entitled, "Standard Based Science Education and Critical Thinking", posits that the results of his study are aimed to identify the content goals in science that require critical thinking from the perspective of pre-service teachers. In addition, Chen, Tolmie, \& Wang (2017) entitled "Growing the Critical Thinking of School Children in Taiwan using Analects of Confucius" points out that the result of her study is aimed to cultivate critical thinking in school children in Taiwan using Analects Confucius. Based on his research, the value of critical thinking in the context of learning dialogue is a strategic approach to critical thinking. According to Tohir 2019 this study results from the fact that Indonesia has released the achievement of the Program for International Student Assessment (PISA). This release is conducted together with 72 countries participating in the PISA survey. The 2015 survey results, on Tuesday, December 6, 2016, showed a significant increase in educational attainment in Indonesia by 22.1 points. The result puts Indonesia in fourth place in case of student achievement improvement compared to the previous survey results in 2012, from 72 countries taking the PISA test. The rank was lower (69 out of 79 countries) than PISA 2015 (Pradita, Maswar, Tohir, Junaidi, \& Hadiyansah, 2021; Anggraena, 2019). Meanwhile, Indonesia's PISA results in 2018 fell compared to PISA results in 2015, namely for the mathematics category, Indonesia was ranked 7 th from the bottom (73) with an average score of 379. Meanwhile, in 2015 Indonesia received an average score of 386 out of 70 Countries (Pradita et al., 2021; Tohir, 2019).

The syntax model of Research-Based Learning adopted from Arifin (2017), as there are three main steps that should be grouped in the stages of Research-Based Learning, involving the followings:

1) Exposure stage, which means that collecting information based on inquiry and searching the literature on a particular topic (focused topic),

2) Experience stage, which alludes to identifying and formulating problems based on literature studies and experimental experiences,

3) Capstone, which means a stage of conveying a plan or idea in giving solution problem or measurement or computation method. 
RBL is a very important technique for learning and teaching by using research element in the learning process. As we know that new knowledge rapidly occurs in the world in the period of technology and influence information come from around the world. RBL is very important which be increase not only knowledge but be increase cognitive, ability to think, consideration and creative learning (Sota \& Peltzer, 2017). A person's thinking ability in identifying and constructing mathematical formulas is needed to foster students' understanding of the material and produce meaningful learning (Ula, Meliyana, Ilahiyah, \& Tohir, 2020; Tohir et al., 2018).

Two-dimensional arithmetic is needed to solve problems employing critical thinking. Based on Tohir et al. (2018), the arithmetic sequence is the sequences of numbers, the differences among which exist between two consecutive terms are a fixed number. The difference of two consecutive tribes signifies difference, in this study denoted by $d$. Arithmetic sequence is known by $U_{1}, U_{2}, U_{3}, \ldots, U_{n}, \ldots$ which is consecutive from a arithmetic sequence $U_{1}+U_{2}+U_{3}+\ldots+U_{n}+$.. with ( )

To measure the students' critical thinking skill, it is needed an instrument that complies with the indicators used. The researchers arranged the newest and most difference on test instrument of the previous researches. The instrument used elaborates two-dimensional Arithmetics that consist of columns and rows, to be precise column $\mathrm{j}$ and $\mathrm{i}$. $\mathrm{N}$ means the number of columns and $\mathrm{m}$ is the number of rows. The differences between the first number and the before next number are expressed differently. The following table is the elaboration.

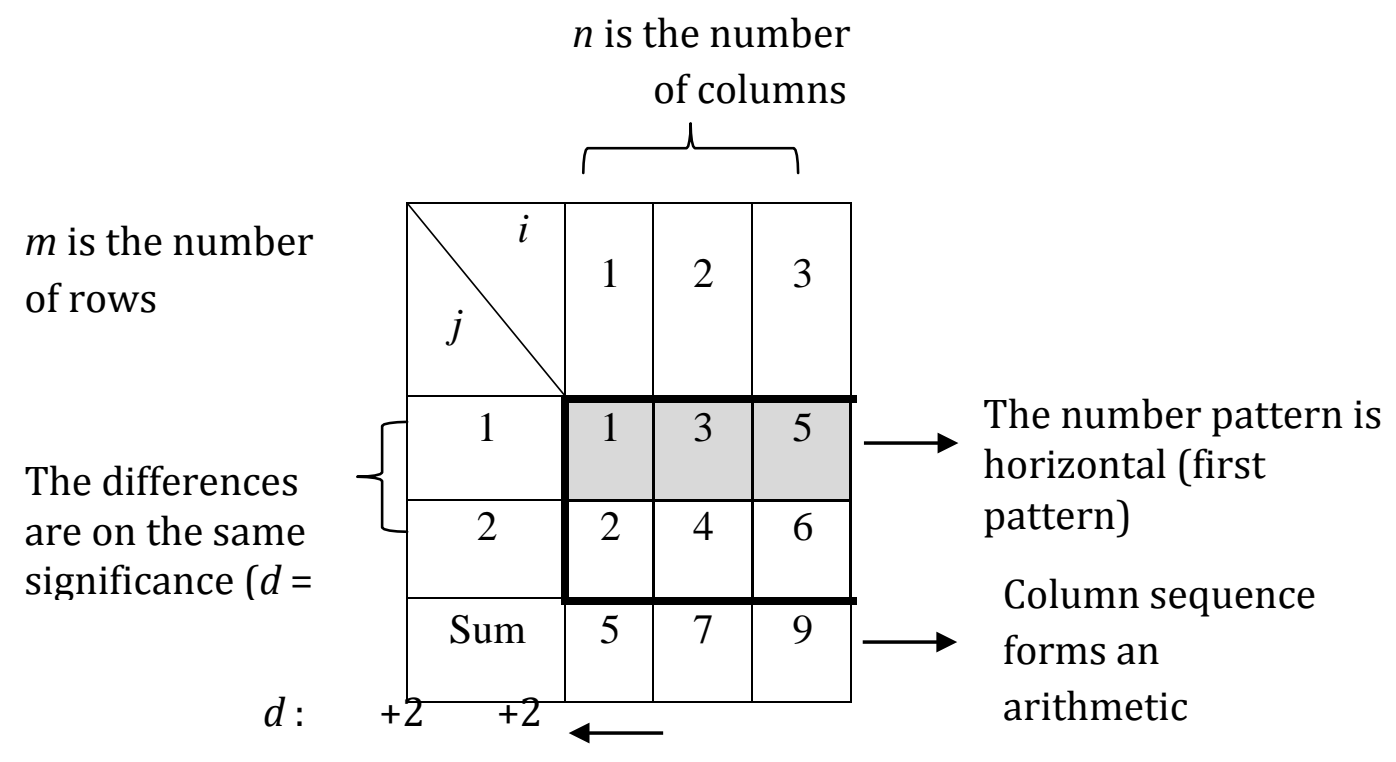

\section{RESEARCH METHODS}

This study used a triangulation research method, namely a combination of qualitative and quantitative methods. According to Saryono (M Tohir, Maswar, Mukhlis, Sardjono, \& Selviyanti, 2021), qualitative research is a research that is used to investigate, describe, explain, discover the quality or features of social influence that cannot be explained, measured, or illustrated through a quantitative 
approach. The quantitative method is obtained by using a learning outcome test and the qualitative method is obtained using a questionnaire and interview. there are 3 questions pre-test and 3 post-test.

The research design was a complete experimental design in that the random sampling was operative for determining control and experiment groups from the certain population on design Pre-test and post-test only control design. The research subjects were the students of XI IPA 1 and XI IPA 2 of Senior High School Muhammadiyah Bondowoso, East Java, Indonesia, each class consists of 30 students.

The form of research design is true experimental design, the main characteristic is that the sample used for the experiment and as a control group is taken randomly from a certain population with a pretest and post-test only design, design Pre-test and post-test only control design.

\begin{tabular}{|cccc|}
\hline $\mathbf{R}$ & $\mathrm{O}_{1}$ & $\times$ & $\mathrm{O}_{2}$ \\
$\mathrm{R}$ & $\mathrm{O}_{3}$ & $-\mathrm{O}_{4}$ \\
\hline
\end{tabular}

(Sugiyono, 2017: 212)

$\mathrm{R}=$ The experimental and control groups were taken randomly

$\mathrm{O}_{1} \& \mathrm{O}_{3}=$ Both groups were observed using a pretest to determine their initial workability. What is expected that the initial workability is the same?

$\mathrm{O}_{2}=$ The results of the experimental class post-test

$\mathrm{O}_{4}=$ Post-test results for the control class

In this design, there are two groups, each of which is randomly selected (R). The first group was given treatment (X) and the other group was not. The treated group is called the experimental class and the untreated group is called the control class. The effect of treatment is (01: 02), in actual research, the effect of treatment is analyzed using t-test statistics. In Sugiyono (2017: 114). Figure 1 shows a triangulation model in which qualitative data is triangulated with quantitative data to determine the impact of Research Based Learning on a two-dimensional arithmetic sequence. 


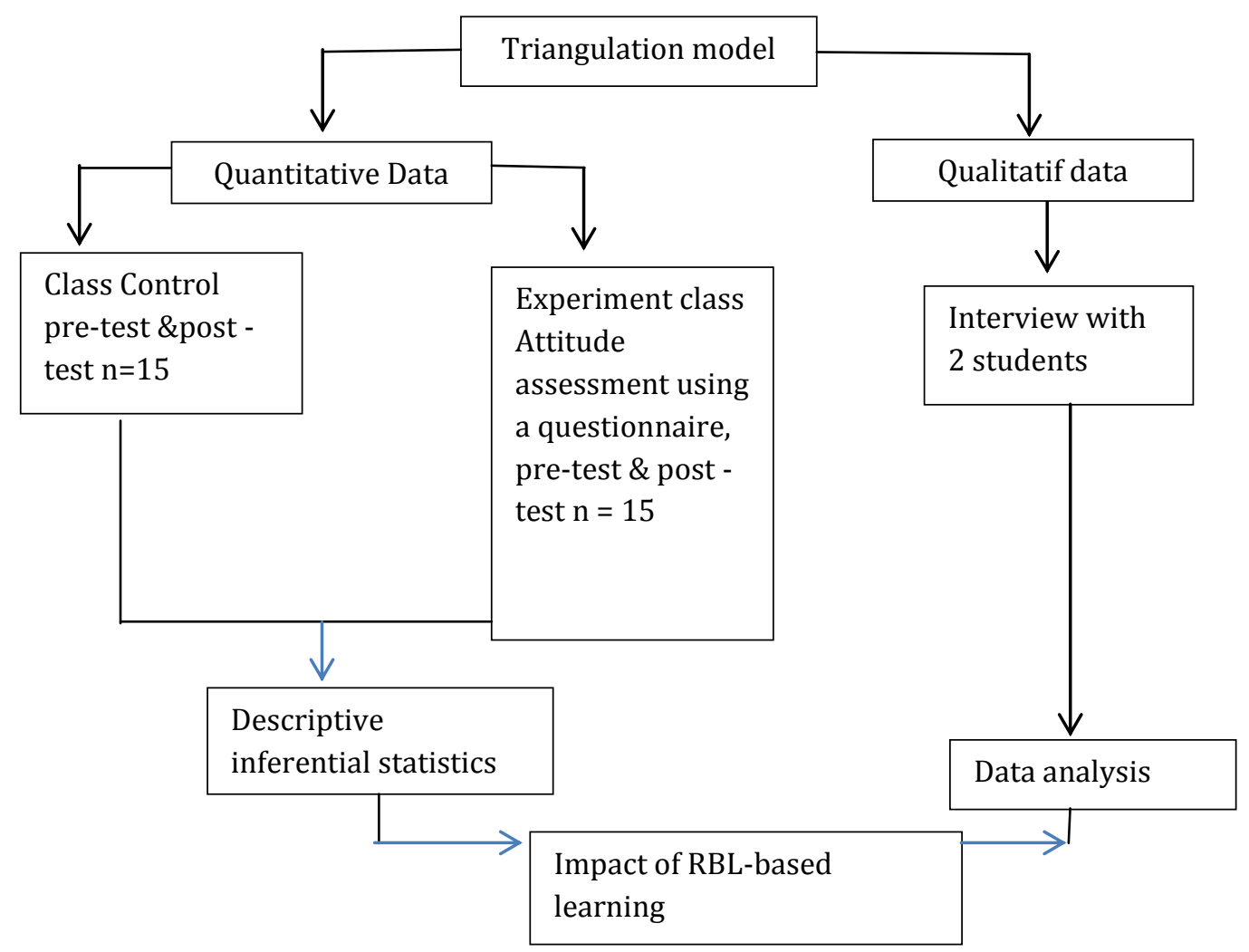

Gambar 1: Triangulation model (Hobri, Dafik, \& Hossain, 2018: 488)

The test results were checked using an answer key and referring to the critical thinking skill indicators that the researchers had made. Then, those critical thinking skills were categorized into level 4, level 3, level 2, level 1 and level 0.

The subjects were chosen based on the following considerations. 4 students were chosen to represent critical thinking level 4, 13 students were chosen to represent critical thinking level 3, and 6 students were chosen to represent critical thinking level 2, 4 students were chosen to represent Critical Thinking level 1, and 3 students were chosen to represent critical thinking level If the data were not saturated, 4 subjects would be possibly taken in accordance of the students' ability. This process was done until the whole data were saturated. The saturation criteria in this study were when 2 students who had the same critical thinking level belonged to the same level of critical thinking skills. The data analysis used the SPSS 20 application for quantitative data and ualitative data using interviews.

\section{RESULTS AND DISCUSSIONS}

Firstly, the preliminary study was done on 30 students of XI.IPA.2 and 30 students of XI.IPA.2. Based on the test and interview, it gathered that the data was saturated, so it was not necessary to take the participants twice. The study based the analysis on the questionnaire and test on each participant.

The results proved that the students at high critical thinking skills in solving Arithmetics problems of two dimensions reached conceptual thinking. Based on the Critical Thinking Ability Level (CTAL), they were in CTAL 3 or defined critical. 
Level 0 (CTAL 0) is called non-reflective thinking (unreflective thinking). The students were characterised in identifying and solving problems that were at the local generalization and global generalization, which was unclear and limited. Level 1 (CTAL 1) is also called the thinking challenged (character thinking) that thinking process, which was also found limited so they had weaknesses concering critical thinking. Thus, the error in solving the problem that was related to the local generalization and Global generalization was clear but limited. Level 2 (CTAL 2 ) is called start thinking (Beginning thinking) characterised by the students being able to recognize the relationship between what is known and what is questioned on the problem faced. Therefore, they were able to solve problems related to the local generalisation but they had not been able to solve problems on global generalization. Level 3 (CTAL 3) is called thinking practice (Practicing Thinking) characterised by the students' thinking ability to analyse activity in solving problems of local generalization and Global generalization. Level 4 (CTAL 4), which was referred to as advanced thinking characterised by the students' thinking ability to analyse activity in solving deep problems about local generalization and Global generalization.

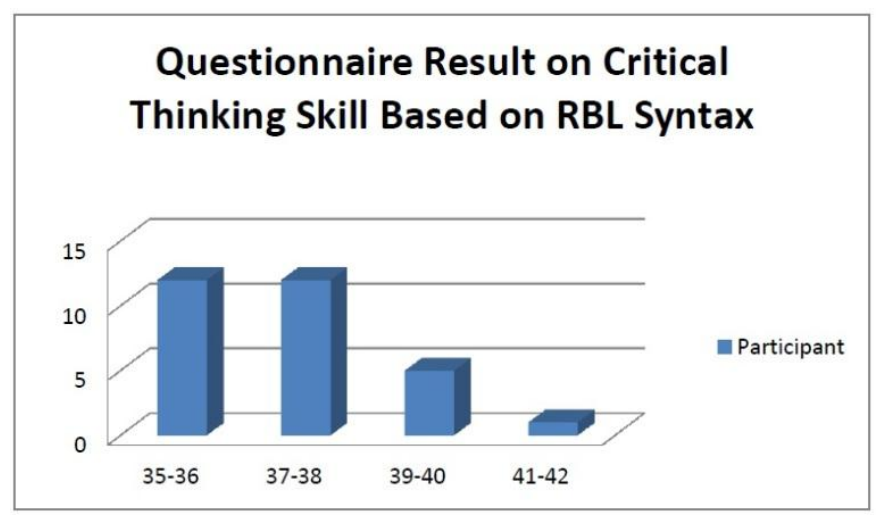

Figure 2. Questionnaire results on Students' Ability

From the 30 questionnaires distributed, the experimental results obtained data from respondents $62 \%$ strongly agree, $82 \%$ agree, Neutral $86 \%$, disagree $62 \%$, strongly disagree $23 \%$. So that you can see the characteristics of each student. shown in table 1 below

Table 1. Summary of Research Results on 30 Participants:

\begin{tabular}{lc}
\hline \multicolumn{1}{c}{ Participants' Answers } & Percentage \\
\hline Strongly Agree ( SA) & $\mathbf{6 2 \%}$ \\
Agree ( A ) & $82 \%$ \\
Neutral ( N) & $86 \%$ \\
Disagree ( D ) & $62 \%$ \\
Strongly Disagree ( SD ) & $23 \%$ \\
\hline
\end{tabular}




\section{Suntusia Suntusia, Dafik Dafik, \& Hobri Hobri}

Table 2. The following criteria interpreted the students' critical thinking skills based on interval.

\begin{tabular}{cc}
\hline Percentage & Level \\
\hline $0 \%-19,99 \%$ & Level 0 \\
$20 \%-39,99 \%$ & Level 1 \\
$40 \%-59,99 \%$ & Level 2 \\
$60 \%-79,99 \%$ & Level 3 \\
$80 \%-100 \%$ & Level 4 \\
\hline
\end{tabular}

From Table 2 Based on questionnaires results on Level 0 and 1, 7 students were on moderate ability in solving Arithmetic problems of two dimensions that were seen from the thinking process belonging to the semi-conceptual part, especially the Critical Thinking Ability Level (CTAL) on CTAL 1 (hardly critical). While students on low ability in solving Arithmetics problems of two-dimension figures were seen from the thinking process belonging to the computational part, especially the Critical Thinking Ability Level (CTAL) on CTAL 0 (Not Critical). This level is characterized by students' being able to only grab the data at the stage of sorting out what was known and asked. Otherwise, it seems like the students were also capable of implementing the plan and checking back the students work. 6 students achieved level 2, 13 students achieved level 3, and 4 people gained level 4 . The following is the student's results on pretest.

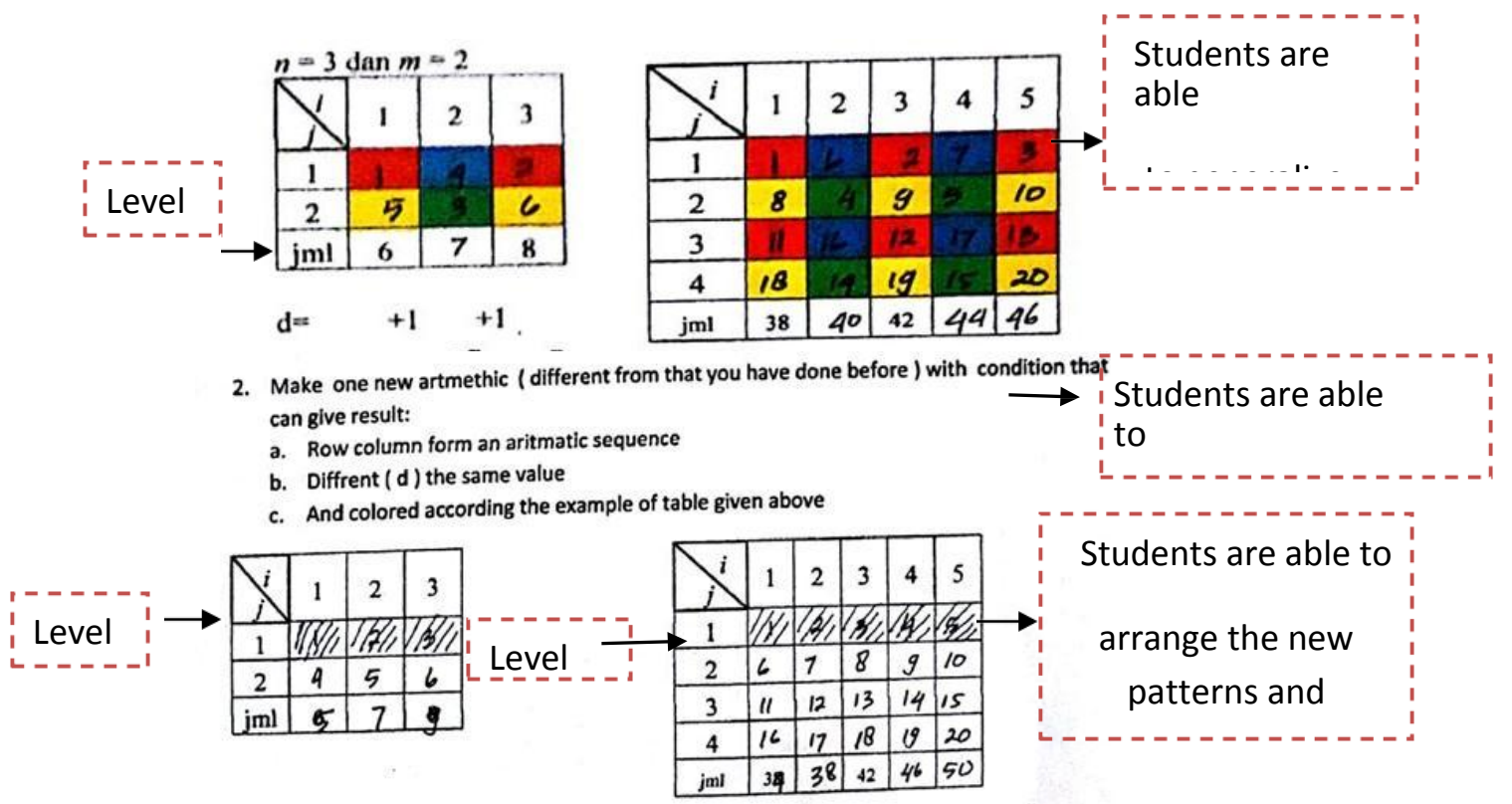

Figure 3. the student's results on pretest. 
The following is the students' results on post-test.

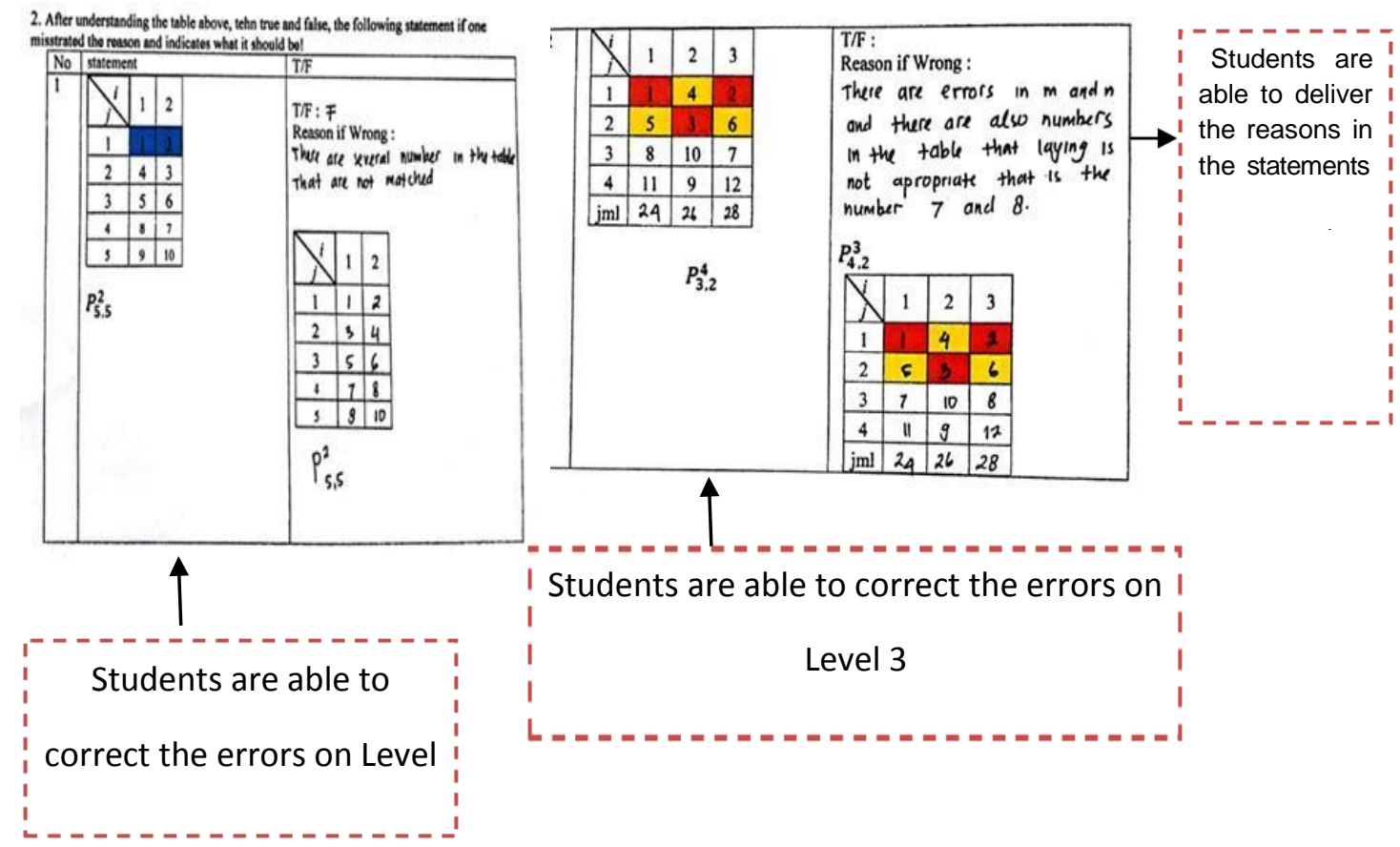

Fogure 4. the students' results on post-test

Interview Transcriptions

Researcher : After you read these questions, what do you comprehend through these questions?

Student : Actually, if the colour and number are the sequences, the other colour can be understandable.

Researcher : What did you get after you did the questions?

Student : Oh. After I completed the questions, I found out that the differences were not evident. Then, the arrow was followed by the sequence number on the right.

Researcher : How did you accomplish question number 2?

Student : I arranged the simple patterns then I added it to the bottom and sideways.

Researcher : How could you comprehend the post-test?

Student : Basically, it was the same as t pre-test Mom. But, I needed to be more concerned about the right and wrong statements and I could give reasonable elaborations.

In the One-Sample statistic output Table it is clear that the research sample $(\mathrm{N})=30$ people on average on learning achievement for control class achieved 71,9333 and experimental class gained 74,0333. For the standard deviation, 10,8254 is on the control class and 9,03817 is for the experimental class. The standard error for the experimental class is 1.6501, while the control class is 2,00513 with regard to the pre-test value. 
Table 3. One-Sample Statistics

\begin{tabular}{lllll}
\hline & N & Mean & $\begin{array}{l}\text { Std. } \\
\text { Deviation }\end{array}$ & $\begin{array}{l}\text { Std. Error } \\
\text { Mean }\end{array}$ \\
\hline Control Class & 30 & 71.9333 & 10.98254 & 2.00513 \\
Experiment Class & 30 & 74.0333 & 9.03817 & 1.65014 \\
\hline
\end{tabular}

Table 4. One-Sample Test

\begin{tabular}{llllllll}
\hline \multicolumn{1}{l}{ Test Value $=\mathbf{3 0}$} \\
\hline & $\mathrm{t}$ & $\mathrm{df}$ & $\begin{array}{l}\text { Sig. }(2- \\
\text { tailed) }\end{array}$ & $\begin{array}{l}\text { Mean } \\
\text { Difference } \\
\text { the Difference }\end{array}$ \\
\hline Control Class & 20.913 & 29 & .000 & 41.93333 & 37.8324 & 46.0343 \\
Experiment Class & 26.685 & 29 & .000 & 44.03333 & 40.6584 & 47.4082 \\
\hline
\end{tabular}

This study could not be accomplished through this new type of test. The researchers expected the students with high critical thinking ability to generalize the patterns that had been found. Next, students with medium critical thinking ability were able to achieve the shading aspects. Those with low ability were able to reach the new pattern aspects. Based on the interpretation of the result of in $t-$ test value on SPSS, there is a significant difference between the control class and the experimental class proved by 0,000 , and then there is a significant difference. The data that we got was significant between the control class and the experimental class below 0.05. After we interpreted in t-table, we found a figure of 2.04 with freedom degrees of 0.025 and results from t-count 0.000 . Thus, the hypothesis was accepted since it was below 0.025 .

In the one-sample statistic output table, it is obvious that the research sample $(\mathrm{N})$ covers 30 students. The average learning achievement for the control class is 75.3000 while the experimental class is 80.1333 , with means of standard deviation of 10.90761 for the control class and 8,993 23 for the experimental class. Additionally, the standard error for the experiment class is 1.64193 while the control class is 1.99145 for the post-test value.

Table 5. One-Sample Statistics

\begin{tabular}{lccll}
\hline & N & Mean & $\begin{array}{c}\text { Std. } \\
\text { Deviation }\end{array}$ & $\begin{array}{c}\text { Std. Error } \\
\text { Mean }\end{array}$ \\
\hline Control Class & 30 & 75.3000 & 10.90761 & 1.99145 \\
Experiment Class & 30 & 80.1333 & 8.99323 & 1.64193 \\
\hline
\end{tabular}

Based on table 5, it has fulfilled the parametric t-test analysis because the number of samples for each class is 30 students. 
The Level of Critical Thinking Skill on Solving Two-Dimensional....

Table 6. One-Sample Test

\begin{tabular}{|c|c|c|c|c|c|c|}
\hline \multicolumn{7}{|c|}{ Test Value $=30$} \\
\hline & \multirow[b]{2}{*}{$\mathrm{t}$} & \multirow[b]{2}{*}{$\mathrm{df}$} & \multirow[b]{2}{*}{ Sig. (2- tailed) } & \multicolumn{3}{|c|}{$\begin{array}{l}95 \% \text { Confidence Interval } \\
\text { of the Difference }\end{array}$} \\
\hline & & & & $\begin{array}{c}\text { Mean } \\
\text { Difference }\end{array}$ & Lower & Upper \\
\hline Control Class & 22.747 & 29 & .000 & 45.30000 & 41.2270 & $\begin{array}{c}49.373 \\
0\end{array}$ \\
\hline Experiment Class & 30.533 & 29 & .000 & 50.13333 & 46.7752 & $\begin{array}{c}53.491 \\
5 \\
\end{array}$ \\
\hline
\end{tabular}

The results in the study were in line with Forawi's study (2016) entitled "Standart Based Science Education and Critical Thinking" aimed to identify the content goals of science. It is required on critical thinking from the perspective of pre-service teachers. On the other hand, Chen et al. (2017) entitled "Growing The Critical Thinking of School Children in Taiwan Using Analects of Confucius" proved that on cultivating critical thinking in school children in Taiwan using Analects Confucius. According to his research, the critical thinking value in the context of learning dialogue is a strategic approach to critical thinking. However, this study used the subject class of XI IPA 1 (a second-grade science class at senior high school) and XI IPA2 (another second-grade science class at senior high school) at SMA Muhammadiyah Bondowoso through Arithmetic materials, especially Arithmetic Two Dimensions on a new type of problem. The interpretation result of the value is high which means the research is successful. Therefore, a person's critical thinking skills need to be continuously honed and improved for all levels of education (Munawwarah et al., 2020). Because students are able to think critically will be able to solve problems effectively (Arifani, As'ari, \& Abadyo, 2017; Chukwuyenum, 2013; Peter, 2012). A person who has the able to think critically will be very influential in his daily life, that is, he will always make the right and good decisions (Tohir et al., 2020). This is reinforced by the opinion of Ennis (Munawwarah et al., 2020) which states that critical thinking is logical and reflective thinking that is focused on making decisions about what to believe or what to do.

\section{CONCLUSIONS}

Based on the analysis, the study has concluded that 6 students test results have met the indicators of critical thinking skills. The subjects were classified into various levels of critical thinking skills. 8 students were at critical thinking level 4 , 6 students were at critical thinking level 3, and 6 students were at critical thinking level 2, 5 students were critical thinking ability level 1 , and 5 students were at critical thinking level 0 . If the data were not saturated, then 4 more subjects would be involved it accordance with the students' ability until the data was saturated. Students with low critical thinking skill were at Level 0 indicating quality of being hardly creative since it was classified as the criteria of non-reflective thinking. There is a significant difference between the control class and the experimental class. This current study cannot be achieved through this new type of test. The 
researchers expect students with high critical thinking ability to generalize the patterns that have been found. Students are can reach the shading aspects. Students on low ability are able to touch upon the new pattern aspects. The interpretation result of the t-test value with SPSS proves that there is a significant difference between the control class and the experimental class is proved by a figure of 0,000 and there is a significant difference. While the data that we get are significant between the control class and the experimental class, indicated by a figure below 0.05. After it has been interpreted on the table through 2.04 with freedom degrees of 0.025 , $t$-count is evident at 0.000 . So the hypothesis is accepted because it is below 0.025 .

Suggestions for teachers are expected to provide more practices or more creative learning materials to develop the critical mindset of students. Also, the students should be encouraged to do the exercises on a challenging problem to hone their mindset and they should not easily give up trying on finding a solution when they are having difficulty.

\section{Recommendations For Further Research}

Create thesis subject with research-based learning. Study the different research methodology for an appropriate technique of research based learning

\section{ACKNOWLEDGEMENT}

I Would Like to thank to Post Graduate Mathematics Education of Faculty of Teacher Training and Education, University of Jember Indonesia, and Gratefully acknowledge the Support Form Dean of Faculty of Teacher Training and Education, University of Jember Indonesia, Headmaster of Senior High School Muhammadiyah Bondowoso Indonesia.

\section{REFERENCES}

Abidin, Z., \& Tohir, M. (2019). Keterampilan berpikir tingkat tinggi dalam memecahkan deret aritmatika dua dimensi berdasarkan taksonomi bloom. Alifmatika: Jurnal Pendidikan Dan Pembelajaran Matematika, 1(1), 44-60. https://doi.org/10.35316/alifmatika.2019.v1i1.44-60

Anggraena, Y. (2019). Pengembangan kurikulum matematika untuk meningkatkan kemampuan siswa dalam penalaran dan pemecahan masalah. Alifmatika: Jurnal Pendidikan Dan Pembelajaran Matematika, 1(1), 15-27. https://doi.org/10.35316/alifmatika.2019.v1i1.15-27

Arifani, N. H., As'ari, A. R., \& Abadyo, A. (2017). Proses berpikir siswa kelas viii dalam menyelesaikan soal matematika timss materi besar sudut dalam bentuk geometris. Jurnal Pendidikan: Teori, Penelitian, Dan Pengembangan, 2(7), 946954. http://dx.doi.org/10.17977/jptpp.v2i7.9677

Arifin, Z. (2017). Mengembangkan instrumen pengukur critical thinking skills siswa pada pembelajaran matematika abad 21. Jurnal THEOREMS (The Original Research of Mathematics), 1(2), 92-100. 
http://dx.doi.org/10.31949/th.v1i2.383

Chen, P., Tolmie, A., \& Wang, H. (2017). Growing the critical thinking of schoolchildren in Taiwan using the Analects of Confucius. International Journal of Educational Research, 84(1), 43-54. https://doi.org/10.1016/j.ijer.2017.02.002

Chukwuyenum, A. N. (2013). Impact of critical thinking on performance in mathematics among senior secondary school students in Lagos State. IOSR Journal of Research \& Method in Education, 3(5), 18-25.

Faizah, S., Nusantara, T., Sudirman, S., \& Rahardi, R. (2020). Exploring students' thinking process in mathematical proof of abstract algebra based on Mason's framework. Journal for the Education of Gifted Young Scientists, 8(2), 871-884. https://doi.org/10.17478/jegys.689809

Forawi, S. A. (2016). Standard-based science education and critical thinking. Thinking Skills and Creativity, 20(1), 52-62. https://doi.org/10.1016/j.tsc.2016.02.005

Haryani, F. Y., Hidayatullah, M. F., Yusuf, M., \& Asrowi. (2019). Problem-based learning for teaching Fiqh: An overview of its impact on critical thinking skill. AIP Conference Proceedings, 2194(1), 20038. https://doi.org/10.1063/1.5139770

Hobri, H., Dafik, D., \& Hossain, A. (2018). The implementation of learning together in improving students' mathematical performance. International Journal of Instruction, 11(2), 483-496. https://doi.org/10.12973/iji.2018.11233a

Iakovos, T. (2011). Critical and creative thinking in the English language classroom. International Journal of Humanities and Social Science, 1(8), 82-86.

Mudayen, Y. M. V., \& Dalyono, C. T. (2018). The effectiveness of problem-based learning model to improve critical thinking skills for high school students. International Journal of Science and Research (IJSR), 8(11), 783-791.

Munawwarah, M., Laili, N., \& Tohir, M. (2020). Keterampilan berpikir kritis mahasiswa dalam memecahkan masalah matematika berdasarkan keterampilan abad 21. Alifmatika: Jurnal Pendidikan Dan Pembelajaran Matematika, 2(1), 37-58. https://doi.org/10.35316/alifmatika.2020.v2i1.3758

Peter, E. E. (2012). Critical thinking: Essence for teaching mathematics and mathematics problem solving skills. African Journal of Mathematics and Computer Science Research, 5(3), 39-43. https://doi.org/10.5897/AJMCSR11.161

Pradita, D. A. R., Maswar, M., Tohir, M., Junaidi, J., \& Hadiyansah, D. N. (2021). Analysis of reflective student analogy reasoning in solving geometry problems. Journal of Physics: Conference Series, 1783(1), 12105. https://doi.org/10.1088/1742-6596/1783/1/012105

Sota, C., \& Peltzer, K. (2017). The effectiveness of research based learning among master degree student for health promotion and preventable disease, faculty 
of public health, khon Kaen University, Thailand. Procedia-Social and Behavioral Sciences, 237(1), 1359-1365. https://doi.org/10.1016/j.sbspro.2017.02.226

Sugiyono, S. (2017). Quantitative, Qualitative and $R$ \& D Research Methods. Bandung: Alfabeta CV.

Suntusia, S., Dafik, D., \& Hobri, H. (2019). The Effectiveness of Research Based Learning in Improving Students' Achievement in Solving Two-Dimensional Arithmetic Sequence Problems. International Journal of Instruction, 12(1), 1732. https://doi.org/10.29333/iji.2019.1212a

Tohir, M, Maswar, M., Mukhlis, M., Sardjono, W., \& Selviyanti, E. (2021). Prospective teacher's expectation of students' critical thinking process in solving mathematical problems based on Facione stages. Journal of Physics: Conference Series, 1832(1), 12043. https://doi.org/10.1088/1742$6596 / 1832 / 1 / 012043$

Tohir, Mohammad. (2019). Hasil PISA Indonesia Tahun 2018 Turun Dibanding Tahun 2015. Retrieved December 3, 2019, from Paper of Matematohir website: https://matematohir.wordpress.com/2019/12/03/hasil-pisaindonesia-tahun-2018-turun-dibanding-tahun-2015/

Tohir, Mohammad, Abidin, Z., Dafik, D., \& Hobri, H. (2018). Students Creative Thinking Skills in Solving Two Dimensional Arithmetic Series Through Research-Based Learning. Journal of Physics: Conference Series, 1008(1), 012072. https://doi.org/10.1088/1742-6596/1008/1/012072

Tohir, Mohammad, Maswar, M., Atikurrahman, M., Saiful, S., \& Rizki Pradita, D. A. (2020). Prospective teachers' expectations of students' mathematical thinking processes in solving problems. European Journal of Educational Research, 9(4), 1735-1748. https://doi.org/10.12973/EU-JER.9.4.1735

Ula, F. F., Meliyana, R., Ilahiyah, R., \& Tohir, M. (2020). Hak Waris Bagi Anak Hasil Zina dalam Kajian Ilmu Matematika dan Hukum Islam. FOKUS: Jurnal Kajian Keislaman Dan Kemasyarakatan, 5(2), 197-220. https://doi.org/10.29240/jf.v5i2.1797 